\title{
Influence of storage time and temperature on the chemical composition of the essential oil of Hyptis pectinata L. Poit
}

JESUS, A.S. ${ }^{*}$; BLANK, A.F.'; ALVES, M.F."; ARRIGONI-BLANK, M.F.'; LIMA, R.N.2; ALVES, P.B. ${ }^{2}$ 'Universidade Federal de Sergipe - UFS, Departamento de Engenharia Agronômica, Av. Marechal Rondon, s/n ${ }^{\circ}$. - Jardim Rosa Elze CEP: 49100-000 - São Cristóvão - Sergipe - Brasil. 2Universidade Federal de Sergipe - UFS, Departamento de Química, Av. Marechal Rondon, s/no. - Jardim Rosa Elze CEP: 49100-000 - São Cristóvão Sergipe - Brasil *Autor para correspondência: alexdabio@gmail.com.

ABSTRACT: Hyptis pectinata, popularly known as "sambacaitá", is a native medicinal herb used by local people for treating disease. Its pharmacological, antimicrobial, and medicinal properties have been reported in several studies. The essential oil of the leaves is rich in terpene compounds responsible for its properties. Because there are factors that can influence the chemical composition of essential oils, the objective of this study was to evaluate the influence of storage on Hyptis pectinata essential oil for 360 days at two different temperatures. The essential oil was distilled from dried leaves of seven-month-old plants using the hydrodistillation method, and the chemical composition was determined using GC-MS and GC/FID. The effects of storage on the essential oil Hyptis pectinata were tested over the course of a year $(0,15,30,60$, $90,120,150,180,240,300$, and 360 days $)$, using two temperatures: room $\left( \pm 32^{\circ} \mathrm{C}\right)$ and freezer $\left(-20^{\circ} \mathrm{C}\right)$. The predominant compounds in the essential oil are $\beta$-caryophyllene, caryophyllene oxide, and germancrene $\mathrm{D}$. The concentration of the chemical constituents of the essential oil varied depending on the storage temperature, and over the 360 days. The storage of the essential oil at room temperature over one year resulted in higher concentrations of $\beta$-elemene, $\alpha$-copaene, germacrene D, caryophyllene oxide, and (E,E)- $\alpha$-farnesene and lower content of $\alpha$-humulene and $\beta$-caryophyllene, compared to the results obtained from storing the essential oil in a freezer. These results indicate that the essential oil should be stored in a freezer, which provides greater stability to the concentration of the chemical constituents.

Keywords: aromatic and medicinal plant, post-harvest, sambacaitá, chemical constituents.

RESUMO: Influência do tempo de armazenamento e da temperatura na composição química do óleo essencial de Hyptis pectinata L. Poit. Hyptis pectinata, conhecida popularmente como Sambacaitá é uma erva medicinal nativa utilizada pela população local para o tratamento de enfermidades, cujas propriedades farmacológicas, antimicrobianas e medicinais foram relatadas em diversos estudos. O óleo essencial das folhas é rico em compostos terpênicos responsáveis pelas suas propriedades. Devido à existência de fatores que podem influenciar a composição química dos óleos essenciais, o objetivo deste trabalho foi avaliar a influência do armazenamento do óleo essencial Hyptis pectinata durante 360 dias em duas temperaturas diferentes. O óleo essencial foi destilado a partir de folhas secas de plantas de sete meses de idade, utilizando o método de hidrodestilação e a composição química foi determinada usando CG-EM e CG-DIC. Os efeitos do armazenamento no óleo essencial Hyptis pectinata foram testados ao longo de um ano $(0,15,30,60,90,120,150$, $180,240,300$ e 360 dias), utilizando duas temperaturas: ambiente $\left( \pm 32^{\circ} \mathrm{C}\right)$ e freezer $\left(-20^{\circ} \mathrm{C}\right)$. Os compostos predominantes no óleo essencial foram o $\beta$-cariofileno, óxido de cariofileno e germancreno $D$ e houve variação na concentração dos constituintes químicos do óleo essencial, dependendo da temperatura de armazenamento, bem como ao longo dos 360 dias. O armazenamento do óleo essencial, à temperatura ambiente ao longo de um ano resultou em maiores concentrações de $\beta$-elemeno, $\alpha$-copaeno, germacreno $D$, óxido de cariofileno e $(E$, E) - $\alpha$-farneseno e menores teores de $\alpha$-humuleno e $\beta$-cariofileno, quando comparado com os resultados obtidos a partir de armazenamento do óleo essencial no freezer. Estes resultados 
indicam que o óleo essencial deve ser estocado no freezer, o que propicia maior estabilidade na concentração dos constituintes químicos.

Palavras-chave: Planta Aromática e Medicinal. Pós-colheita. Sambacaitá. Constituintes Químicos.

\section{INTRODUCTION}

Hyptis pectinata or 'sambacaitá' (Hyptis pectinata L. Poit.) (Lamiaceae) produces an essential oil that can be extracted by steam distillation from its dried leaves and inflorescences. This essential oil has several beneficial properties, including antinociceptive, anti-inflammatory, and antimicrobial properties against Gram (+) and Gram (-) strains of bacteria, such as the Candida genus and Cryptococcus neofarman, and antiStreptococcus-mutans activity (Arrigoni-Blank et al., 2008; Raymundo et al., 2011; Santos et al., 2008).

The $H$. pectinata essential oil is widely used for inflammation, bacterial infections, pain and for cancer treatment (Bispo et al., 2001). The chemical composition of the essential oil, based on both qualitative and quantitative analyses, varies significantly. Specifically, a variety of mono- and sesquiterpene compounds has been identified to compose the essential oil, where the sesquiterpenes were the predominant species (Santos et al., 2008).

According to the literature, the compounds with the highest frequencies of occurrence in the essential oil are $\beta$-caryophyllene, ranging from $18.34 \%$ to $45.09 \%$, caryophyllene oxide, ranging from $18.00 \%$ to $38.05 \%$, and calamusenone, ranging from $24.68 \%$ to $48 \%$, in which $\beta$-caryophyllene is the main component of the $\mathrm{H}$. pectinata oil (ArrigoniBlank et al., 2008; Blank et al., 2010; Raymundo et al., 2011; Santos et al., 2008; Silva et al., 2008; Tchoumbougnang et al., 2005). The chemical compositions of the essential oil of the $\mathrm{H}$. pectinata leaves from three different geographical regions also showed variations. The main compounds in each oil were as follows: sabinene, $\beta$-caryophyllene (both from India), $\sigma$-cymene (West Africa) and $\beta$-elemene (Fiji archipelago) (Pietschmann, et al., 1998). While in other study, the $H$. pectinata essential oil produced in Africa showed high levels of $\beta$-caryophyllene $(22.10 \%)$, it also showed high levels of germacrene D $(28.00 \%)$ (Tchoumbougnang et al., 2005).

Thus, we note that the study of the factors influencing the chemical compositions of essential oils may contribute to the maximized production of a particular active principle or of a compound of interest in medicinal and aromatic plants (Simões et al., 2007). The process of storing essential oils is crucial for maintaining their quality because these oils tend to be unstable in the presence of light, heat, oxygen and moisture, suffering from many degradation reactions that hamper their conservation (Simões et al., 2007).

Due to the medicinal value of the essential oil from $H$. pectinata (Santos Neto et al., 2007) and the fact that several factors may influence its concentration, yield and chemical composition, the objective of the present study was to investigate the influence of storage time in different temperatures on the Hyptis pectinata essential oil of the Active Germplasm Bank of the Federal University of Sergipe (BAG/UFS).

\section{MATERIAL AND METHODS \\ Plant material}

The study was conducted at the Experimental Farm "Campus Rural da UFS", located in the municipality of São Cristóvão, state of Sergipe (SE), Brazil (latitude $11^{\circ} 00^{\prime} \mathrm{S}$ and longitude $37^{\circ} 12^{\prime} \mathrm{W}$ ). The genotype $H$. pectinata (SAM 015) was grown by and obtained from the BAG/UFS, Voucher specimen $\left(n^{\circ}\right.$. 18993) identified by Dr. Ana Paula Prata was deposited in the Biology Department of Federal University of Sergipe.

The spacings used between the plants and rows were $0.50 \mathrm{~m}$ each, and the fertilizer applied consisted of $6000 \mathrm{~kg} \mathrm{ha}^{-1}$ of cattle manure and 1000 $\mathrm{kg} \mathrm{ha}^{-1}$ of NPK (nitrogen-phosphorus-potassium) (6-24-12 + micronutrients). The experiments were initiated on January 7,2011 and harvested on August 12, 2011. The leaves were collected of plants cutting at $25 \mathrm{~cm}$ above the soil. To assess the moisture content, three $50 \mathrm{~g}$ samples were taken and dried in an air-circulating oven at $105^{\circ} \mathrm{C}$ for 48 $\mathrm{h}$, these samples were weighed fresh after drying. To evaluate the storage effects on the oil, all of the materials after harvest were dried at $40^{\circ} \mathrm{C}$ in an aircirculating oven for $4 \mathrm{~d}$, and then they were distilled by steam distillation using a Clevenger apparatus for 140 min (Andrade \& Casali, 1999). Subsequently, the collected oils were stored in amber flasks at the Laboratory of Plant Science, Agricultural Engineering Departament, UFS. The average temperature in the laboratory was $32^{\circ} \mathrm{C}$, while that in the freezer was $-20^{\circ} \mathrm{C}$. The concentrations $(\%)$ were estimated based on the average dry weight $(\mathrm{v} / \mathrm{w})$ obtained from three samples of $100 \mathrm{~g}$ (Larcher, 2000). All of the experiments were conducted in a completely randomized design using a $2 \times 11$ factorial scheme,

Rev. Bras. PI. Med., Campinas, v.18, n.1, supl. I, p.336-340, 2016. 
where two storage environments (in a freezer at $-20^{\circ} \mathrm{C}$ and at $\pm 32^{\circ} \mathrm{C}$, room temperature) and eleven times $(0,15,30,60,90,120,150,180,240,300$ and 360 days) were tested.

\section{Chemical analysis of the essential oil}

Qualitative analyses of the chemical compositions of the essential oil were performed using a gas chromatograph coupled to a mass spectrometer (GC-MS, Shimadzu model QP 5050A), which was equipped with an auto-injector AOC-20i (Shimadzu) and a J \& W Scientific fused silica capillary column ( $5 \%$ phenyl-95\% dimethylpolysiloxane) (30 $\mathrm{m} \times 0.25 \mathrm{~mm}$ id, $0.25 \mathrm{mM}$ film) with a helium carrier gas flow rate of $1.2 \mathrm{~mL} \mathrm{~min}^{-1}$. The temperature of the system was programmed to be $50^{\circ} \mathrm{C}$ for $2 \mathrm{~min}$, and then the temperature was increased at $4^{\circ} \mathrm{C} \mathrm{min}-1$ to $200^{\circ} \mathrm{C}$ and once more increased at $15^{\circ} \mathrm{C} \mathrm{min}$ m $^{-1}$ to $300^{\circ} \mathrm{C}$, where this temperature was maintained for $15 \mathrm{~min}$. The injector temperature was $250^{\circ} \mathrm{C}$, and the temperature at the detector (or interface) was $280^{\circ} \mathrm{C}$. Ethyl acetate $(0.5 \mathrm{~mL})$ was injected at a partitioning rate of 1:100 of the injected volume and a column pressure of $64.20 \mathrm{kPa}$. The MS used an electron capture detector (ECD) operating on electron impact mode with an impact energy of $70 \mathrm{eV}$, a scan interval of 0.50 fragments and a fragment detection range of 40 to $500 \mathrm{Da}$.

By comparisons of the mass spectra with the spectra in the literature (Adams 2007) and spectra from the equipment database (NIST21 and NIST107), the essential oil components were identified. Additionally, the retention times were compared with those from the literature. The Kovats retention index $(\mathrm{KI})$ was determined by injecting a homologous series of $n$-alkanes (C8-C18) and using the same chromatographic conditions as the samples (Van den Dool \& Kratz, 1963). A quantitative analysis of the essential oil components was performed using a Shimadzu GC-17A GC equipped with a flame ionization detector (GC/FID). The device was operated under the same conditions as the GC-MS except for using a fused silica capillary ZB-5 $\mathrm{ms}$ column (5\% dimethylpolysiloxane, $30 \mathrm{~m} \times 0.25$ $\mathrm{mm}$ id, $0.25 \mathrm{mM}$ film). Through the normalization of the area (\%), each constituent was quantified. The concentrations of the compounds were calculated based on their areas and were arranged in order of their GC elution times.

\section{Statistical analysis}

All experiments were performed in triplicate. The data were subjected to an analysis of variance (ANOVA) and a subsequent comparison of averages Scott-Knott test (1974) with significance 5\% $(p<0.05)$ to determine the essential oil content and chemical composition as a function of the storage environment.

\section{RESULTS AND DISCUSSION}

After the third day of drying, the moisture content stabilized in the leaves, indicating that $4 \mathrm{~d}$ of drying at $40^{\circ} \mathrm{C}$ may be considered ideal for the stabilization of the dry weight of the $\mathrm{H}$. pectinata leaves. Regarding the essential oil content, with the storage of the leaves for $4 \mathrm{~d}$ resulted in a content of $0.88 \%(\mathrm{v} / \mathrm{w})$, with a volume of $12 \mathrm{~mL}$, for the essential oil from $1,364 \mathrm{~g}$ of dry leaves.

When evaluating the influence of storage time on the content of the $H$. pectinata essential oil, 36 compounds were identified consistently among the compounds present in the essential oil, where seven of the compounds were considered to be main components (Table 1).

Of the compounds found in the essential oil of $H$. pectinata, $\beta$-caryophyllene was notable due to its high concentration in both of the temperature, ranging from $50.95 \%$ to $39.53 \%$ when stored at room temperature and from $44.88 \%$ to $53.60 \%$ when stored in the freezer. In addition, caryophyllene oxide was also found to be a significant compound, ranging from $14.71 \%$ to $22.08 \%$ at room temperature and from $14.58 \%$ to $18.15 \%$ in the freezer. These results agree with other studies performed on the chemical composition of the $H$. pectinata essential oil, where the presence of the abovementioned compounds have been reported and are characteristic for this species (Arrigoni-Blank et al., 2008; Blank et al., 2010; Nascimento et al., 2008; Raymundo et al., 2011; Santos et al., 2008; Tchoumbougnang et al., 2005).

For room temperature storage as a function of the storage time of the essential oil, there were significant differences in the concentrations of compounds. The essential oil without having been stored ( 0 days) had statistically higher concentrations for 4 compounds than those for the stored samples (15 to 360 days): $\alpha$-humulene had its highest concentration on day $0(2.79 \%)$, germacrene $D$ was highest on days 0 and 15 (9.08\% and $9.25 \%)$, both showing significant drop content throughout the storage time. The $\alpha$-copaene was highest on days 0 and $300(2.97 \%$ and $2.88 \%)$ and (E,E)- $\alpha$-farnesene was highest on days 15, 30 and $60(1.75 \%, 2.56 \%$ and $2.59 \%$ ). The opposite results were found for caryophyllene oxide (300 and 360 days), $\beta$-caryophyllene (15, 30 and 90 days) and $\beta$-elemene (300 and 360 days), whose concentrations in the essential oil were significantly higher when stored than those found in the essential oil when not stored (Table 1).

When the samples were stored in the freezer, significant influences on the concentrations of all of the compounds in the essential oil were found: $\alpha$-humulene had its highest concentration on day 0 $(2.79 \%)$, a-copaene was highest on day $0(2.97 \%)$,

Rev. Bras. PI. Med., Campinas, v.18, n.1, supl. I, p.336-340, 2016. 
TABLE 1. Average values for the concentrations of the chemical constituents of the essential oil of $H$. pectinata as a function of the storage temperature and time.

\begin{tabular}{|c|c|c|c|c|c|c|c|c|c|c|c|c|}
\hline \multirow[b]{3}{*}{ Compound } & \multirow[b]{3}{*}{$\mathbf{R I}$} & \multicolumn{11}{|c|}{ Storage Time $\left( \pm 32^{\circ} \mathrm{C}\right)$} \\
\hline & & 0 & 15 & 30 & 60 & 90 & 120 & 150 & 180 & 240 & 300 & 360 \\
\hline & & \multicolumn{11}{|c|}{ Room Temperature } \\
\hline a-copaene & 1375 & $2.97 \mathrm{aA}$ & $2.48 \mathrm{aD}$ & $2.56 \mathrm{aC}$ & $2.71 \mathrm{aB}$ & $2.41 \mathrm{aD}$ & $2.64 \mathrm{aC}$ & $2.66 \mathrm{aC}$ & $2.73 a \mathrm{~B}$ & $2.66 \mathrm{aC}$ & $2.88 \mathrm{aA}$ & $2.78 \mathrm{aB}$ \\
\hline$\beta$-elemene & 1389 & $6.57 \mathrm{aG}$ & $7.27 \mathrm{aF}$ & $7.11 \mathrm{aF}$ & $7.47 \mathrm{aE}$ & $7.21 \mathrm{aF}$ & $8.19 \mathrm{aD}$ & 8.34aD & $8.70 \mathrm{aC}$ & $8.98 \mathrm{aB}$ & $9.28 \mathrm{aA}$ & $9.13 a A$ \\
\hline$\beta$-caryophyllene & 1420 & $44.88 \mathrm{aC}$ & $50.56 \mathrm{bA}$ & $50.95 \mathrm{bA}$ & $46.13 \mathrm{aC}$ & $49.59 \mathrm{bA}$ & $45.14 b C$ & $45.39 \mathrm{bC}$ & $43.85 \mathrm{bD}$ & $47.33 \mathrm{bB}$ & $39.53 \mathrm{bE}$ & $42.91 \mathrm{bD}$ \\
\hline$\alpha$-humulene & 1455 & $2.79 \mathrm{aA}$ & $2.49 \mathrm{aC}$ & $2.53 \mathrm{aB}$ & $2.58 \mathrm{bB}$ & $2.37 \mathrm{aC}$ & $2.41 \mathrm{bC}$ & $2.42 \mathrm{aC}$ & $2.41 \mathrm{bC}$ & $2.36 \mathrm{bC}$ & $2.47 \mathrm{bC}$ & $2.21 \mathrm{bD}$ \\
\hline germacrene D & 1481 & $9.08 \mathrm{aA}$ & $9.25 \mathrm{aA}$ & $8.75 \mathrm{aB}$ & $8.68 \mathrm{aB}$ & $7.44 \mathrm{aC}$ & $0.00 \mathrm{bD}$ & $6.61 \mathrm{bD}$ & $5.64 \mathrm{bE}$ & $4.44 \mathrm{bF}$ & $4.33 \mathrm{bF}$ & $3.22 \mathrm{aG}$ \\
\hline$(E, E)-\alpha$ - farnesene & 1503 & $0.00 \mathrm{aA}$ & $1.75 \mathrm{bA}$ & $2.56 \mathrm{bA}$ & $2.59 \mathrm{bA}$ & $2.28 \mathrm{bB}$ & $1.64 \mathrm{bC}$ & $1.59 b \mathrm{~b}$ & $1.48 \mathrm{bD}$ & $1.28 \mathrm{bE}$ & $1.33 \mathrm{bE}$ & $0.62 \mathrm{aE}$ \\
\hline \multirow[t]{2}{*}{ caryophyllene oxide } & 1582 & $15.54 \mathrm{aF}$ & $14.71 \mathrm{aF}$ & $14.80 \mathrm{aF}$ & 17.16aE & $16.72 \mathrm{aE}$ & 18.33aD & 18.80aD & $19.92 \mathrm{aC}$ & $20.55 a \mathrm{~B}$ & $22.08 \mathrm{aA}$ & $21.82 \mathrm{aA}$ \\
\hline & & \multicolumn{11}{|c|}{ Freezer Temperature $\left(-20^{\circ} \mathrm{C}\right)$} \\
\hline a-copaene & 1375 & $2.97 \mathrm{aA}$ & $2.31 \mathrm{bD}$ & $2.45 \mathrm{aC}$ & $2.57 \mathrm{bB}$ & $2.25 \mathrm{bD}$ & $2.39 b D$ & $2.37 \mathrm{bD}$ & $2.41 \mathrm{bD}$ & $2.45 \mathrm{bC}$ & $2.58 \mathrm{bB}$ & $2.38 \mathrm{bD}$ \\
\hline$\beta$-elemene & 1389 & $6.57 \mathrm{aA}$ & $5.78 \mathrm{bC}$ & $5.71 b \mathrm{C}$ & $5.91 b C$ & $5.54 \mathrm{bD}$ & $6.13 \mathrm{bB}$ & $6.09 \mathrm{bB}$ & $6.15 \mathrm{bB}$ & $6.22 \mathrm{bB}$ & $6.58 \mathrm{bA}$ & $6.08 \mathrm{bB}$ \\
\hline$\beta$-caryophyllene & 1420 & $44.88 \mathrm{aD}$ & $53.60 \mathrm{aA}$ & $53.46 \mathrm{aA}$ & $46.24 \mathrm{aD}$ & 53.23aA & $49.38 \mathrm{aC}$ & $49.32 \mathrm{aC}$ & $49.30 \mathrm{aC}$ & 51.31aB & $46.15 \mathrm{aD}$ & $51.14 a \mathrm{~B}$ \\
\hline a-humulene & 1455 & $2.79 \mathrm{aA}$ & $2.45 \mathrm{aC}$ & $2.52 \mathrm{aB}$ & $2.78 \mathrm{aA}$ & $2.44 \mathrm{aC}$ & $2.55 \mathrm{aB}$ & $2.53 \mathrm{aB}$ & $2.54 \mathrm{aB}$ & $2.62 \mathrm{aB}$ & $2.70 \mathrm{aA}$ & $2.43 \mathrm{aC}$ \\
\hline germacrene D & 1481 & $9.08 \mathrm{aA}$ & $7.60 \mathrm{bD}$ & $7.82 \mathrm{bD}$ & 8.63aB & $7.59 \mathrm{aD}$ & $8.15 \mathrm{aC}$ & $8.03 \mathrm{aC}$ & $8.04 \mathrm{aC}$ & $7.65 \mathrm{aD}$ & $8.25 \mathrm{aC}$ & $0.00 \mathrm{bC}$ \\
\hline$(E, E)-\alpha$ - farnesene & 1503 & $0.00 \mathrm{aB}$ & $2.50 \mathrm{aD}$ & $2.66 \mathrm{aB}$ & $2.88 \mathrm{aA}$ & $2.56 \mathrm{aC}$ & $1.90 \mathrm{aE}$ & $1.89 \mathrm{aE}$ & $1.91 \mathrm{aE}$ & $1.91 \mathrm{aE}$ & $1.99 \mathrm{aE}$ & $0.00 \mathrm{bE}$ \\
\hline caryophyllene oxide & 1582 & $15.54 \mathrm{aC}$ & $14.66 \mathrm{aD}$ & $14.58 \mathrm{aD}$ & $17.44 \mathrm{aA}$ & $15.46 \mathrm{aC}$ & $16.92 \mathrm{bB}$ & $16.84 \mathrm{bB}$ & $16.86 \mathrm{bB}$ & $16.67 \mathrm{bB}$ & $18.15 \mathrm{bA}$ & $16.57 \mathrm{bB}$ \\
\hline
\end{tabular}

The averages that are followed by the same lowercase letters among the storage temperatures and by the same uppercase letters among the storage times did not differ by the Scott-Knott test $(p \leq 0.05)$. RI = Retention Index.

both showing significant drop content throughout the time. The (E,E)-a-farnesene was highest on day 60 (2.88\%), caryophyllene oxide was highest on days 60 and $300(17.44 \%$ and $18.15 \%), \beta$-caryophyllene was highest on days 15,30 and $90(53.60 \%, 53.46 \%$ and $53.23 \%)$, $\beta$-elemene was highest on days 0 and 300 $(6.57 \%$ and $6.58 \%)$ and germacrene $D$ was highest on day $0(9.08 \%)$ (Table 1$)$.

The harvesting and post-harvesting are extremely important for obtaining essential oil with higher quality, composition and for the product reaches the end of production chain (Ehlert et al., 2013; Silva et al., 2013). Thus, it is necessary to establish criteria to insure quality during processing and storage (Souza et al., 2015). However, essential oil suffer numerous reactions, making the key storage quality and preservation of the physical and chemical composition (Guimarães et al., 2008; Silva et al., 2013).

Storage effects on the essential oil composition in the branches of Ocimum basilicum have also been shown, specifically, eugenol and linalool concentrations were found to increase during storage (Silva et al.,2003). Another study found differences in the chemical composition of the essential oil of Mentha arvensis L. over time (Shalaby et al.,1988). Similar to the results found for some of the compounds in the essential oil of $H$. pectinata, most likely due to prolonged storage and degradation of the compounds.

However, in a study on the effects of the drying period on the leaves and on the inflorescence of the essential oil of sweet basil, an increase in linalool content from $45.18 \%$ to $86.80 \%$ in the fresh leaves after 5 days of drying was also observed (Carvalho Filho, 2006). Additionally, an increase in linalool content from $80.68 \%$ to $92.62 \%$ in the fresh inflorescence after 11 days of drying was observed (Carvalho Filho, 2006). Storage of the $H$. pectinata essential oil at room temperature resulted in statistically higher concentrations when compared to those stored in the freezer for the following compounds. The $\beta$-elemene (at all storage times), $\alpha$-copaene (15, 60 to 360 days), germacrene $D$ (15, 30 and 360 days), caryophyllene oxide (120 to 360 days) and (E, E)- $\alpha$-farnesene, (360 days). However, lower concentrations were found for a-humulene $(60,120$ to 360 days) and $\beta$-caryophyllene (15, 30,90 to 360 days). Overall, the storage times during the year influenced the concentrations of the compounds present in the essential oil. Similarly, significant differences were found for the compounds analyzed when stored in different places. Therefore, these results show the chemical instability of the

Rev. Bras. PI. Med., Campinas, v.18, n.1, supl. I, p.336-340, 2016. 
$H$. pectinata essential oil when stored at room temperature, which suggests that degradative processes are occurring during storage. For instance, in a study of Cymbopogon citratus (Lemon grass), the essential oil components were shown to suffer degradation over time (Guimarães et al., 2008). However, the temperature of the storage location could also cause the essential oil compounds to favor oxidative processes.

\section{CONCLUSION}

Storage of the $H$. pectinata essential oil in the two different environments also resulted in variations of the chemical composition of the oil over time during the 360-day study, demonstrating the instabilities of the chemical components in the essential oil when stored at room temperature and that storage in a freezer is recommended because this environment provided greater chemical constituent concentration stabilities. Many compounds essential oil like caryophyllene oxide e $\beta$-caryophyllene are influence by storage environment suggesting its storage in the freezer.

\section{ACKNOWLEDGEMENTS}

The authors are grateful to FAPITEC/SE, $\mathrm{CNPq}$ and CAPES for their financial support.

\section{REFERENCES}

ADAMS, R. P. Identification of Essential Oil Components by Gas Chromatography/Mass Spectrometry. 4th edition. Allured: Carol Stream, I, 803p, 2007.

ANDRADE, F.M.C.; CASALI, V.W.D. Plantas medicinais e aromáticas: relação com o ambiente, colheita e metabolismo secundário. Viçosa: UFV/DFT, 1999, $139 p$

ARRIGONI-BLANK, M. F. et al. Antinociceptive activity of the volatile oils of Hyptis pectinata L. Poit. (Lamiaceae) genotypes. Phytomedicine, v. 15, n. 1, p. 334-339, 2008.

BISPO, M. D. et al. Antinociceptive and antiedematogenic effects of the aqueous extract of Hyptis pectinata leaves in experimental animals. Journal of Ethnopharmacology, v. 76, n. 1, p. 81-86, 2001.

BLANK, A F. et al. Influência do horário de colheita e de secagem no óleo essencial de Hyptis pectinata L . Poit ( Lamiaceae ). Scientia, v. 6, n. 10, p. 1-5, 2010.

CARVALHO FILHO, J. L. et al. Influence of the harvesting time, temperature and drying period on basil (Ocimum basilicum L .) essential oil. Brazilian Journal of Pharmacognosy, v. 16, n. 1, p. 24-30, 2006.

EHLERT, P.A.D. et al. Influência do horário de colheita sobre o rendimento e composição do óleo essencial de erva-cidreira brasileira [Lippia alba (Mill.) N. E. Br.].
Revista Brasileira de Plantas Medicinais, v. 15, n. 1, p. 72-77, 2013.

GUIMARÃES, L. G. D. L. et al. Influência da luz e da temperatura sobre a oxidação do óleo essencial de capim-limão (Cymbopogon citratus (D.C.) STAPF). Química Nova, v. 31, n. 6, p. 1476-1480, 2008.

LARCHER, W. Ecofisiologia vegetal. São Carlos: Rima, 2000. 531p.

NASCIMENTO, P. et al. Hyptis pectinata essential oil: chemical composition and anti- Streptococcus mutans activity. Oral Diseases, v. 14, n. 6, p. 485-489, 2008.

PIETSCHMANN, M. et al. Volatile constituents of Hyptis pectinata Poit. (Lamiaceae). Journal of Essential Oil Research, v. 10, n. 5, p. 550-552, 1998.

RAYMUNDO, L. J. R. P. et al. Characterisation of the anti-inflammatory and antinociceptive activities of the Hyptis pectinata (L.) Poit essential oil. Journal of Ethnopharmacology, v. 134, n. 3, p. 725-732, 2011.

SANTOS NETO, A. L. et al. Crescimento inicial de sambacaitá (Hyptis pectinata L.). Revista Ciência Agronômica, v. 38, n. 3, p. 310-316, 2007.

SANTOS, P. O. et al. Chemical composition and antimicrobial activity of the essential oil of Hyptis pectinata (I.) Poit. Química Nova, v. 31, n. 7, p. 16481652, 2008.

SCOTT, A. J.; KNOTT, M. A. A cluster analysis method for grouping means in the analysis of variance. Biometrics. Raleigh, v.30, n.3, p. 507-512, 1974.

SHALABY, A.S. et al. Post harvest studies on herb and oil of Mentha arvensis L. Egyptian Journal Horticultural, v.15, n.2, p.213-24, 1988.

SILVA, F. et al. Avaliação do teor de óleo essencial de Baccharis trimera (Less.) DC. em diferentes embalagens durante o armazenamento. Revista Brasileira de Plantas Medicinais, v. 15, n. 1, p. 54-58, 2013.

SILVA, F. et al. Teor e composição do óleo essencial de manjericão (Ocimum basilicum L.) em dois horários e duas épocas de colheita. Revista Brasileira de Plantas Medicinais, v. 6, n. 1, p. 33-38, 2003.

SILVA, W. J. et al. Effects of essential oils on Aedes aegypti larvae: Alternatives to environmentally safe insecticides. Bioresource Technology, v. 99, n. 8, p. 3251-3255, 2008.

SIMÕES C. M. O. et al. Farmacognosia: da planta ao medicamento. 6 ed. Porto AlegreFlorianópolis: Editora da UFRGS, 2007. 1102p.

SOUZA, C.R.F. et al. Influência do processo de secagem e condição de armazenamento de extratos secos de Bauhinia forficata e Passiflora alata sobre seu perfil de dissolução. Revista Brasileira de Plantas Medicinais, v. 15 , n. 1, p. $67-75,2015$.

TCHOUMBOUGNANG, F. et al. Aromatic plants of tropical Central Africa. XLVIII. Comparative study of the essential oils of four Hyptis species from Cameroon: $\mathrm{H}$. lanceolata Poit., $H$. pectinata (L.) Poit., $H$. spicigera Lam. and $H$. suaveolens Poit. Flavour and Fragrance Journal, v. 20, n. 1, p. 340-343, 2005.

VAN DEN DOOL, H.; KRATZ, P. D. A generalization of the retention index system including linear temperature programmed gas-liquid partition chromatography. Journal of Chromatography, v. 11, p. 463-471, 1963.

Rev. Bras. PI. Med., Campinas, v.18, n.1, supl. I, p.336-340, 2016. 